\title{
UNIVERSÁLNÍ ŽIVOT A ŽIVOT LIDSKÝ K ontologii přírody u Jana Patočky a Maurice Merleau-Pontyho ${ }^{1}$
}

\author{
Martin Rabas
}

Soudě podle ohlasu, který vyvolala strahovská pozůstalost Jana Patočky, znamená uvedení tohoto souboru do našeho povědomí, přinejmenším pro Patočkovy čtenáře, významný objev. ${ }^{2}$ Ze statí, které byly strahovským rukopisům věnovány, není však zcela zřejmé, jakou filosofii vlastně objevené rukopisy obsahují, a proto ani jaký je jejich filosofický význam, totiž jejich případná relevance pro pochopení Patočkova myšlenkového vývoje či pro řešení živých filosofických otázek. ${ }^{3}$ Jan Puc představil stanovisko obsažené v těchto rukopisech jako filosofii života. ${ }^{4}$ Martin

1 Děkuji recenzentovi a redaktorům časopisu Reflexe za cenné podněty. Zvláště bych chtěl poděkovat Janu Halákovi za důkladné pročtení pracovních verzí studie a řadu zpřesňujících návrhů a Filipu Karfíkovi za rozhodující podnět pro výklad Patočkovy koncepce přírody.

2 Za toto uvedení vděčíme Filipu Karfíkovi. Viz F. Karfík, Patočkova strahovská pozůstalost a jeho odložené opus grande, in: Kritický sborník, 20, 2000/2001, str. 125-160; F. Karfík, Odyssea zkonečnělého absolutna. Patočkưv filosofický vývoj mezi lety 1936-1964, přel. M. Ritter, in: I. Chvatík (vyd.), Myšlení Jana Patočky očima dnešní fenomenologie, Praha 2009, str. 25-49. Do cizojazyčného kontextu uvedla strahovské rukopisy Ana Santos: A. Santos, Das Fragment Nitro a Svět (Das Innere und die Welt). Einführung, in: I. Chvatík (vyd.), Studia Phaenomenologica (Romanian Journal for Phenomenology), VII, Jan Patočka and the European Heritage, Bucharest 2007, str. 17-25.

3 Přesněji řečeno, tato výhrada se týká té části pozůstalosti, kterou bychom zjednodušeně mohli nazvat „systematickou“, protože obsahuje filosofii, jejíž ambicí je svým výkladem obsáhnout celek jsoucího. Toto označení má sloužit především k odlišení od druhé významné a zároveň rozsáhlejší části pozůstalosti, která obsahuje přípravné práce k filosofii dějin (k tomu viz F. Karfík, Patočkova strahovská pozůistalost), pro niž měla patrně filosofická koncepce „,systematických rukopisů“ poskytnout metafyzické založení. Obě zmíněné skupiny rukopisů ovšem představují systematické práce v obecnějším smyslu slova, proto bude vhodné nalézt pro jejich odlišení výstižnější označení.

4 J.Puc, $O$ životě a smrti. Patočkova koncepce člověka a jeho životního úkolu ve válečných rukopisech, in: Reflexe, 36, 2009, str. 25-30. 
Ritter je v polemické reakci označil za filosofii vědomí. ${ }^{5}$ Výklad, který překonává toto rozdělení a ukazuje souvislost obou určení, navrhl Karel Novotný. ${ }^{6}$ Dosud však nebyl podniknut pokus vyložit možnou jednotnou tezi spočívající za Patočkovými radikálními vyjádřeními týkajícími se vědomí na jedné straně a života na straně druhé. Chtěli bychom se o to pokusit a navázat přitom na interpretaci, kterou rozvinul Karel Novotný a jež staví do základu rukopisné filosofické koncepce pojem života ve smyslu př́rody. Domníváme se totiž, že jsou to právě Patočkova překvapivá vyjádření o přírodě, v nichž je nejostřeji formulováno stanovisko obsažené ve strahovských rukopisech a jeho specifikum v rámci Patočkovy tvorby.

Pojem přírody Patočka koncipuje výslovně jako pojem metafyzický. V duchu svého dlouho zastávaného přesvědčení jej konstruuje na podkladě deskriptivního poznání prožívání a chápe ho v jistém ohledu jako prostřredek sebepoznání. V této souvislosti pro něj fenomenologický pojem přírody představuje klíč k otázce, jak myslet člověka zároveň jako součást celku jsoucího a plně individuální bytost. Myšlenka universálního života, jenž je současně životem individua, má charakter velkorysého metafyzického gesta, jehož cílem je podle všeho přispět k oživení života člověka moderní doby. Svým založením na pojmu jednotné a zároveň vnitřně protikladné přírody se tato koncepce v rámci Patočkovy doposud známé tvorby zřetelně vymyká. Je proto otázka, zda v případě strahovské pozůstalosti nemáme před sebou dosud nezhodnocený filosofický koncept - tuto otázku se však následujícím textem můžeme pokusit nanejvýš jasněji formulovat.

Záměr postavit fenomenologii na podklad metafyzického pojmu př́rody má obdobu ve filosofii Maurice Merleau-Pontyho z let 1956-1961. Podobně jako filosofie strahovských rukopisů je Merleau-Pontyho tvor-

5 M. Ritter, Odcizené nitro. Polemická reakce na článek Jana Puce, in: Reflexe, 38, 2010, str. 99-107. Viz také J. Frei, Odcizené nitro, nebo zúžené vědomí? K reakci M. Rittera na článek J. Puce, in: Reflexe 39, 2009, str. 105-114 a M. Ritter, Nitro a jeho základ. Pokus o shrnutí diskuse k Patočkovým válečným rukopisưm, in: Refle$x e, 40,2011$, str. 99-104. Nověji se autor věnoval interpretaci strahovských rukopisů ve statích: M. Ritter, Nitro a záhada hyletické vrstvy, in: Filosofický časopis, 50, 2011, str. 81-97 a M. Ritter, Life of Inwardness, in: týž, Into the World. The Movement of Patočka's Phenomenology, Cham 2019, str. 31-41.

6 K. Novotný, Koncept hlubší korelace životní v raných rukopisech Jana Patočky, in: Filosofický časopis, 6, 2017, str. 833-853. Viz také M. Rabas, Smyslové vnímání jako vyjadřování bytí u Patočky a Merleau-Pontyho, in: E-LOGOS, 2, 2019, str. 48-74. 
ba z tohoto období vedena snahou pojmout prožívaný celek jako významuplný. Tato snaha má však u obou autorů odlišné zaměření. Oba koncipují pojem přírody proto, aby jim umožnil pochopit vzájemnou provázanost jsoucího. Patočka však tento záměr nechápe jako vlastní cíl, nýbrž jako součást širšího filosofického programu, jehož další částí je výklad specifické povahy lidského života a koncepce jeho naplnění. Tento motiv Patočku vede $\mathrm{k}$ tomu, že prŕírodu koncipuje nejen jako princip jednoty jsoucího, ale i jako princip jeho individuality. Srovnání s Merleau-Pontyho tezemi ukazuje, že Patočkův př́stup dovoluje komplexněji pojmout jednotlivé jsoucno, z Patočkova hlediska pak především lidský život coby život svobodný. Na druhou stranu ze srovnání též plyne, že v jiném ohledu naopak Patočka neuchopuje lidskou svobodu tak radikálně jako Merleau-Ponty. Merleau-Ponty totiž na rozdíl od Patočky předpokládá, že lidské jednání a dějiny určují přírodu i co do jejího bytí. Nahlédneme-li Patočkovy a Merleau-Pontyho teze z hlediska ontologického pojmu přírody, jsou s to se vzájemně osvětlovat. Z tohoto důvodu činíme součástí výkladu ontologie strahovských rukopisů její srovnání s Merleau-Pontyho filosofií přírody, abychom zřetelněji pochopili obě stanoviska z hlediska jejich filosofických mezí a možností.

Jedním z ústředních pojmů, jež si Patočka ve strahovských systematických rukopisech ukládá vymezit, je pojem vzájemného vztahu mezi člověkem a celkem jsoucího. Soudě podle vyjádření v těchto rukopisech a jim předcházejících pracích Patočka pojal tento záměr, protože byl přesvědčen, že tento vztah představuje pro jeho současnost a moderní dobu vůbec klíčový problém. $\mathrm{K}$ řešení tohoto problému prristoupil ve své době originálním způsobem. Domníval se, že jeho uspokojivé řešení předpokládá překročení čistě lidské perspektivy, z níž vlastní vztah k celku jsoucího spontánně spatřjujeme, ovšem zároveň takové překročení, které bude provedeno na základě lidské perspektivy a nakonec kvůli ní samé, totiž pro její skutečné pochopení. Důraz, s nímž Patočka daný problém kladl, je tedy položen na lidský život. Účelem překonání čistě lidské perspektivy a poznání vztahu člověka a celku jsoucího je pro něj vposled pochopení celku zkušenosti. To mělo umožnit realizaci druhého cíle strahovských rukopisů, jímž měla podle všeho být koncepce možnosti smysluplného života, tedy takového života, který př̌kračuje bez- 
prostřední zkušenost a stanovuje si svůj účel s ohledem na zakoušený celek pochopený jako celek jsoucího. ${ }^{7}$

Způsob, jakým Patočka klade otázku po smysluplném životě, vychází ze dvou na první pohled protichůdných zaměření jeho raného díla. V Patočkově raném díle můžeme zhruba rozlišit linii deskriptivně fenomenologickou a linii filosoficko-dějinnou. První směr uvažování Patočka rozvinul především ve svém habilitačním spise Přirozený svět jako filosofický problém. Jednou z ústř̌edních tezí této práce je, že moderní člověk si pomocí prrírodních věd osvojil určité objektivní pochopení sebe samého, což vedlo k zásadní proměně jeho spontánního prožívání. ${ }^{8}$ Z Patočkovy fenomenologické analýzy plyne, že vnitřní život člověka žijícího v předválečném světě je z tohoto důvodu charakterizován svazujícím rozporem. Člověk předválečné doby se na jedné straně nevyhnutelně spontánně identifikuje se svým prožíváním, na druhé straně je pokládá za výslednici předmětných sil, jež vposled tvoří objektivní soustavu prŕírody. Tematizuje-li tedy moderní člověk svou osobní svobodu, v důsledku tohoto porozumění se mu její prožitek jeví jako určitý klam. Z toho důvodu má sklon objektivovat vlastní vnitřní život jako řadu vnitřně nesouvisejících impulsů, pro něž je třeba nalézt odpovídající vybití. Protože takto sám sobě rozumí, také se takovým stává. Cílem zodpovězení otázky po smysluplném životě je v případě Přirozeného světa předvedení osobní jednoty prožívání a korelativní jednoty prožívaného celku jsoucího. ${ }^{9}$ Jinými slovy, Patočka zde usiluje o zachycení té možnosti rozumění sobě samému, v níž se člověk k sobě vztahuje v souladu se svou spontaneitou, čímž se v tomto smyslu stává svobodným.

Druhý, filosoficko-dějinný směr Patočkova raného uvažování rozvíjí tezi, podle které se utváření vnitřního života formuje v dějinách pochopených jako dějiny ducha. Pokus vyložit lidské bytí s pomocí pojmu dějin podnikl Patočka nejprve v několika článcích z poloviny třicátých let. ${ }^{10}$ Posléze, během válečných let, pracoval na rozsáhle a podrobně koncipované filosofii duchovních dějin moderní doby. Přípravné práce k tomuto dílu se dochovaly ve strahovské pozůstalosti spolu s ru-

7 J. Patočka, Studie k pojmu světa, in: týž, Fenomenologické spisy, III/1, vyd. I. Chvatík - P. Kouba, Praha 2014, str. 71-73, 114-123.

8 Týž, Přirozený svět jako filosofický problém, in: týž, Fenomenologické spisy, I, vyd. I. Chvatík - P. Kouba, Praha 2008, str. 136-138. Srv. také týž, Několik poznámek o pojmu „světových dějin “, in: týž, Péče o duši, I, vyd. I. Chvatík - P. Kouba, Praha 1996, str. 47 n.

9 Týž, Fenomenologické spisy, I, str. 136. Srv. také tamt., str. 129-131.

10 Týž, Péče o duši, I, str. 35-58, 107-116. 
kopisy systematického charakteru a dosud nebyly edičně zpracovány a zevrubně vyloženy. Jejich obecná teze je pravděpodobně ve stručnosti vyjádřena v některých systematických manuskriptech. ${ }^{11} \mathrm{~V}$ duchovních dějinách evropského člověka nachází Patočka dvě výrazné myšlenky, jejichž prostřednictvím tyto dějiny interpretuje: je to jednak myšlenka, že předmětné uchopení je atributem ducha a člověk se jeho dosažením stává dějinnou bytostí; jednak je to kontrastní myšlenka, že podstata jsoucna a světa vposled neleží v oblasti objektivna, ale ve sféře nezpředmětnitelného života. Vzájemný vztah obou těchto myšlenek je v každé době spjat se způsobem odpovídání na otázku, co je jsoucno a jeho celek. Myšlenka neobjektivovatelného života jsoucna a světa byla podle Patočky v dějinách postupně opouštěna ve prospěch čistě racionálního uchopení a praktického ovládnutí zpředmětnělé prrírody. ${ }^{12} \mathrm{Z}$ Patočkových vyjádření vyplývá, že toto zrušení vzájemného spojení objektivace a nezpředmětnitelnosti jsoucího v moderní době se obráží v rozporu vnitřního života člověka. Z hlediska filosofie dějin se otázka jednoty zkušenosti, resp. možnosti smysluplného života, ukazuje jako otázka, již není možné zodpovědět pouze na půdě prožívání, nýbrž teprve na podkladě vztahu lidského prožívání k celku jsoucího pochopeného na základě nezpředmětnitelného života.

Záměr Přirozeného světa pochopit jednotu objektivního jsoucna jakožto osobní jednotu prožívání je ve strahovských systematických rukopisech rozširren o cíl pochopit jednotu zkušenosti jakožto jednotu jsoucího, které je co do své podstaty živé. Rozvinutí Patočkova staršího záměru tímto způsobem předpokládá rozšíření původního fenomenologického pole tak, aby zahrnovalo pojmy bytí jsoucího a jeho celku. Analýza zkušenosti má nyní nejen odhalit jednotný vztah prožívání a jeho korelátu, ale též život jsoucího. Skutečné fenomenologické poznání pak podle Patočky nutně obnáší metafyzické gesto výkladu deskriptivní analýzy, gesto, které určí popisovaný život co do jeho bytí, a tím deskriptivní poznání plně vyjádří. Tímto způsobem má být předvedena jednota jsoucího jako takového jako jednota života, jenž tvoří podklad jednoty zkušenosti. Teprve na tomto základě pojatá jednota zkušenosti dovoluje Patočkovi položit otázku po smysluplném životě, tedy otázku, jakým způsobem se má individuální prožívání k celku jsoucího vztáhnout. Tuto

11 Jedná se především o rukopisy Úvod. O dvojím zpuisobu filosofování (in: J. Patočka, Fenomenologické spisy, III/1, str. 9-14), Nitro a duch (tamt., str. 21-30) a Studie к ројти světa (tamt., str. 72, 108).

12 Tamt., str. 72. 
nedokončenou cestu, již Patočka ve strahovských systematických rukopisech podnikl, se zde pokusíme stručně vyložit.

Projekt, jehož celkový rámec jsme se pokusili načrtnout, Patočka rozpracoval v několika rukopisných verzích, z nichž žádná nemá charakter hotového díla a jejichž vzájemný vztah není jasný. Pro účely našeho záměru rozlišujeme tři verze, jimž odpovídají dva delší manuskripty a jedna skupina kratších rukopisů: 1. rukopis s incipitem VIII. Úkoly, které si může klásti fenomenologická teorie subjektivity..., ${ }^{13}$ 2. manuskripty Úvod. O dvojím zpuisobu filosofování, Nitro a duch, Nepředmětné a zpředmětnělé nitro, Svět a predmětnost, Nitro, čas, svět, 3. rukopis Studie k pojmu světa. ${ }^{14}$

Lze konstatovat, že všechny rukopisné verze se tematicky různí do té míry, že patrně nepředstavují jednoduše novější verze podobné či shodné argumentace. Zároveň jsou natolik tematicky spřízněné, že pravděpodobně představují odlišná provedení jednoho záměru či realizace jeho různých částí. Tak, jak se dochovaly, však zjevně netvoří jednotné dílo. Do kontextu jejich výkladu proto nezbytně patří otázka, jakým zpo̊sobem mohou být jako celek vykládány. Pokusíme se na tuto otázku odpovědět. Můžeme identifikovat shodný základní rys rukopisných verzí, který se týká vymezení jejich celkového záměru a ústředních pojmů, pomocí nichž má být realizován.

Jisté vymezení záměru zamýšleného filosofického díla nacházíme v manuskriptu Úvod. O dvojím zpuisobu filosofování, který stojí v čele skupiny kratších rukopisů. Východiskem tohoto vymezení je vylíčení historického protikladu mezi subjektivně a objektivně pojatou filosofií. „Subjektivní filosofie“ spatřuje podle Patočkova vymezení vše pod zorným úhlem osobního významu a životní autenticity, jejím úběžným bodem je proto sebepoznání. „Objektivní filosofie“ naopak nahlíží li-

13 Editoři systematických manuskriptů činí v incipitu užitý výraz „,fenomenologická teorie subjektivity“ nadpisem celého nedokončeného rukopisu. Toto slovní spojení sice vhodně postihuje obsah prvního dochovaného oddílu „VIII.“, avšak z fragmentu posledního dochovaného oddílu „IX.“ je zjevné, že Patočkův záměr byl podstatně širší. Z tohoto důvodu uvádíme název rukopisu v souladu s územ zavedeným Filipem Karfíkem ve studii Patočkova strahovská pozůstalost a jeho odložené opus grande.

14 Rukopisné verze řadíme podle námi předpokládaného data vzniku od nejstarší. 
bovolné jsoucno jako součást neosobního, objektivního celku jsoucího, jejím cílem je tudíž předmětné poznání. ${ }^{15}$ Oba tyto sklony filosofování charakterizuje jednostranné zaujetí. Zatímco subjektivní filosofie nedisponuje pojmem skutečného poznání celku veškerenstva, objektivní filosofie nezná subjektivní sebepoznání. Ve prospěch jednoho principu je v obou způsobech filosofování obětován ten druhý, či přesněji řečeno vzájemný vztah obou. To ve svém důsledku vede ke ztrátě možnosti člověka rozpoznat se zároveň jako individuum i jako součást celku jsoucího a brání to pochopení podstaty předmětného poznání. Sebepoznání i poznání vyžaduje podle Úvodu propojení osobního a kosmologického způsobu filosofování, v němž oba způsoby získají nový význam. Patočka má v úmyslu založit poznání celku jsoucího v sebepoznání a současně je pojmout jako nezbytnou součást sebepoznání.

Z Patočkovy interpretace dvou způsobů filosofování plynou určité metafyzické konsekvence, jež se ve svém úhrnu skládají v osnovu jeho vlastního filosofického stanoviska. Původním metafyzickým určením je podle Úvodu jednota subjektivního a objektivního. Ta pak nemůže být pochopena na podkladě zpředmětnění subjektu, protože podle Patočkova soudu tento plán antické metafyziky není s to dosáhnout svého cíle. Objektivní, kosmologický aspekt filosofického poznání má být naopak založen v sebepoznání, které má kosmický rozměr obsahovat. Pojetí jsoucna má být koncipováno „tak, aby subjektivní stanulo v základu objektivního“. ${ }^{16}$ Úvod chápe subjekt jako zakládající, a zároveň v jiném ohledu jako podstatně odkázaný na objektivitu, tedy analogicky k tomu, jak je uchopen vztah sebepoznání a objektivního poznání. Samy pojmy subjektu a objektu nejsou však v této stati blíže určeny.

$\mathrm{S}$ touto formulací celkového záměru je věcně spřízněna teze prvních dvou oddílů manuskriptu Studie k pojmu světa, které de facto plní roli úvodu celého rukopisu. Tyto oddíly jsou věnovány vymezení pojmu smyslu jako takového a dějinně-filosofickému přehledu pojímání „smyslu světa a jsoucna“. Patočka v nich přehlíží vývoj „staré metafyziky“, jejž v principu chápe jako postup směrem ke stále větší radikalizaci předmětného uchopení světa a jsoucna, původně chápaných jako podstatně živé. Odpovědí na tuto radikalizaci je posléze radikálně subjektivní položení otázky po smyslu jsoucna. ${ }^{17}$ Potud postupuje Studie ve shodném duchu jako Úvod. Nový prvek výkladu představuje pojem života. Ten je

15 J. Patočka, Fenomenologické spisy, III/1, str. 10 n.

16 Tamt., str. 14.

17 Tamt., str. 72. 
nyní postaven na místo, které mělo být podle Úvodu přiděleno revidovanému pojmu subjektu.

Pomocí rýsování vzájemných vztahů zde Patočka vymezuje ústřední pojmy smysl a život. Život charakterizuje jako bytostné tíhnutí ke smyslu jako svému pólu. Tento pól pak chápe jako „vnitřní určení“ života. ${ }^{18}$ Ze smyslu coby vnitřního určení lidského života vychází jeho veškeré tendence, účely, prostředky, významy a konečně i smyslové vnímání, zkrátka všechny další podoby smyslu, jež jsou, na rozdíl od vnitřního určení života, spojeny s jistou mírou objektivace. Život je zde ale zároveň charakterizován jako podstatné určení jsoucna jako takového. Tato myšlenka je vyjádřena zejména v Patočkově filosoficko-dějinné črtě: Svět a jsoucno byly v počátcích metafyziky vykládány jako život a objektivace tohoto života, přičemž pojem objektivního jsoucna byl posléze z této původní provázanosti vyňat. Je zjevné, že Patočka chce provázanost živého a předmětného obnovit, a to tak, že život vyloží jako vnitřní určení jsoucího jako takového. Podobně jako v Úvodu je zde na podklad života, resp. subjektu jakožto sebevztahu postaveno jsoucno, resp. objekt.

Poslední rukopis nadepsaný VIII. Úkoly... představuje zjevný fragment, svým celkovým rozvržením nicméně odpovídá ostatním dvěma rukopisným verzím. Rukopis sestává ze dvou oddílů ve výrazně odlišném stádiu rozpracování; první, z větší části dokončený, je věnován výkladu „subjektivní skutečnosti“" na základě intencionální analýzy, zatímco druhý, pouze započatý, vypracování „speciální metafyziky“, mezi jejíž úkoly náleží výklad „konečné subjektivity ve všech jejích formách“ a objektivity z hlediska „vnitřního života jsoucna“. ${ }^{19}$

Pro záměr vyložit svět a jsoucno na základě pojmů života a subjektu nacházíme v Patočkově uveřejněném díle doklad, který strahovský systematický fragment staví do jasnějšího světla. Shodný úmysl ohlásil Patočka již v nejdůležitějším publikovaném spise svého raného období, ve studii Prrirozený svět jako filosofický problém. ${ }^{20}$ Deskriptivně fenomenologické východisko tohoto díla odpovídá tomu, co bychom spolu s Úvodem mohli nazvat subjektivní filosofií: cílem Přrirozeného světa je přinést důkaz, že jednota zkušenostního světa pramení z jednoty prožívání a že jednota prožívání je v př́ípadě člověka jednotou ducha. ${ }^{21}$ Motivací

18 Tamt., str. 71.

19 Tamt., str. 176 a $289 \mathrm{n}$.

20 J. Patočka, Fenomenologické spisy, I, str. 260 n. Viz F. Karfík, Odyssea zkonečnělého absolutna, str. $27 \mathrm{n}$.

21 J. Patočka Fenomenologické spisy, I, str. 129, 131. 
tohoto kroku je, jak jsme se výše pokusili ukázat, širší snaha překonat rozdvojení v sebeporozumění moderního člověka. Nicméně když Patočka v epilogu celého díla uzavírá svou argumentaci, dává najevo, že tento širší záměr považuje za realizovaný pouze zčásti. Deskriptivně, tj. subjektivně založenou argumentaci Přirozeného světa je podle epilogu nezbytné rozšîrit o spekulativní výklad geneze celku jsoucího, jež bude chápána jako dějiny veškerého života. Mezi strahovskými systematickými rukopisy a filosofickým programem ze závěru Přirozeného světa existuje tedy principiální shoda. Program ze závěru Přirozeného světa načrtává hlavní rysy filosofické koncepce, z nichž, jak uvidíme, lze pravděpodobně v obecné rovině usuzovat, jak měly vypadat celkové kontury záměru, jejž měly realizovat strahovské systematické rukopisy. Patočka v tomto programu obecným, avšak jednoznačným způsobem vymezuje, jaký vztah existuje mezi deskriptivními analýzami a metafyzickým pojmem života a na základě jakého postupu míní od subjektivního východiska deskripce přejít k poznání podstaty jsoucího jako takového.

Program dělí tento postup do dvou kroků. Za základní úlohu filosofie označuje „metafyziku ve vlastním slova smyslu, genuinní filosofii“. Tu vymezuje jako analýzu konstituce lidské zkušenosti a variaci možností zkušenosti jako takové: zatímco konstitutivní analýza znamená popis struktur lidského prožívání, zkušenostní variace rozvíjí deskriptivní poznání, aby dospěla k určení „,základních struktur možné subjektivity“. 22 Na takto vymezeném poli se odvíjí argumentace Přirozeného světa. Uskutečnění této úlohy však filosofii jako takovou nevyčerpává, nýbrž ji v jistém smyslu staví teprve na počátek vlastního úkolu, totiž na počátek metafyzické spekulace. Na podkladě poznání základních struktur možné subjektivity má být uskutečněna druhá úloha, jíž je konstrukce ,universálních dějin“, tj. dějin, do jejichž celku „nepatří pouze dějiny člověka, nýbrž všeho tvorstva“. ${ }^{23}$ Tato interpretace má uchopit dějiny veškerého života jako nadané strukturou, pro niž Patočka přejímá pojmenování „tvořivý vývoj“. Tvořivý vývoj chce chápat jako genezi empirického světa rozvíjejícího se od nejjednodušší konstitutivní činnosti života až k nejvyšším konstitutivním výkonům, tvůrčím aktům ducha. Různé druhy předmětnosti mají v souladu s tím být pochopeny jako konstituované zprvu spontánní, a posléze svobodnou intencionalitou veškerenstva živých bytostí.

\footnotetext{
22 Tamt., str. 260.

23 Tamt.
} 
Je patrné, že program z epilogu Přirozeného světa a celkový záměr rukopisů se v principu shodují. Nad rámec shody se ze závěrečného programu habilitace dozvídáme, jak má dokazování představené teze postupovat a jaká jsou jeho východiska: spekulativní metafyzika života má vycházet $\mathrm{z}$ analýzy naší zkušenosti. Tento plán je patrný ve struktuře manuskriptu s incipitem VIII. Úkoly... a rukopisu Studie k pojmu světa a zčásti také ve skladbě skupiny kratších rukopisů začínajících Úvodem. ${ }^{24}$

3.

Ze shromážděných indicií vyplývá, že Patočka chápal metafyzické pojmy, mezi něž patří pojmy nepředmětného života a celku jsoucího, jako určité rozvinutí fenomenologických deskripcí. V následující části se proto zaměříme na to, jak v dané době charakterizuje podstatné stránky prožívání.

V centru Patočkova fenomenologického zájmu stojí pojem intencionality, ,prožívané zaměřenosti, vztahovosti a teleologie“, coby spojení subjektu a objektu. ${ }^{25}$ Před vznikem strahovských rukopisů osciluje Patočkovo pojímání intencionálního vztahu mezi stanovisky vycházejícími na jedné straně z Husserlovy pozdní fenomenologie a na straně druhé z Heideggerova Bytí a času, přičemž příklon k jedné nebo druhé ze stran Patočka zpravidla vyvažuje její explicitní, či alespoň implicitní kritikou. ${ }^{26}$ Vyústěním těchto protisměrných výbojů je syntetické pojetí, jež Patočka poprvé přednesl, a poté publikoval pod názvem Duch a dvě základní vrstvy intencionality. ${ }^{27} \mathrm{~V}$ podstatných ohledech shodnou, ale rozpracovanější podobu této syntézy nalézáme ve strahovském rukopise s incipitem VIII. Úkoly... Teze této syntézy jsou dále přejaty a zapracovány do výkladů dalších systematických manuskriptů. Jaké tedy jsou hlavní rysy Patočkova originálního pojmu intencionality?

24 Zmínka na str. 82 tamt. ukazuje, jak silnou kontinuitu mezi Studií a Přirozeným světem Patočka spatřoval.

25 Tamt., str. 176.

26 F. Karfík, Odyssea zkonečnělého absolutna, str. 32 n. Naladěnost Patočka akcentuje již v Přirozeném světě. Viz K. Novotný, Koncept hlubší korelace životní $v$ raných rukopisech Jana Patočky, str. 845, pozn. 42.

27 J. Patočka, Duch a dvě základní vrstvy intencionality, přel. P. Mat'ová, in: týž, Fenomenologické spisy, I, str. 290-298. 
Intencionální život má podle Patočky strukturu dvou navzájem se podmiňujících rovin, na jedné straně intencionality příčné, totiž předmětné či aktové, na straně druhé intencionality podélné neboli subjektivní či horizontové. ${ }^{28}$ Příčná intencionalita znamená jednak syntézu prožívajícího v předmětném světě, jednak syntetické pojetí smyslové rozmanitosti v podobě určitých objektů; tímto obojím je zároveň a ve vzájemné provázanosti. Podmínky možnosti syntetického aktu jsou netematicky dány $\mathrm{v}$ intencionalitě podélné a mají charakter nepředmětných intencionálních horizontů. Každý takový horizont spoluurčuje způsob, jakým se objektivujeme, resp. jak se nám věci jeví. Takto intencionální horizont konstituuje relativní jednotu subjektivního a objektivního. ${ }^{29}$ Jednotlivé možnosti naší objektivace se skládají v jedinou celkovou podmínku možnosti našeho života, v tomto smyslu ve „svět“ ${ }^{30}$ Možnosti našeho života jsou však zároveň podmíněny našimi akty. Podmiňování má ale $\mathrm{v}$ případě různých syntetických aktů různý charakter: zatímco každý libovolně spontánní akt proměňuje intencionální horizont podobně, jako pohyb posouvá viditelný obzor, pouze svobodný akt podle Patočky spoluurčuje jeho smysl. Svobodné akty se totiž oproti spontánním vztahují k vyššímu řádu objektivity, k rovině ideality, a jsou realizací lidské bytnosti, za niž Patočka pokládá ducha. ${ }^{31}$ Duch je konečně tou stránkou intencionálního života, která se tvưrčím způsobem vztahuje ke světu jakožto celku. Pojem ducha tedy zachycuje specifické propojení předmětné a horizontové intencionality, které je cílem lidského života. $\mathrm{Z}$ toho důvodu duch představuje klíč k lidskému sebepoznání, a proto také strahovský rukopis Nitro a duch právě tímto pojmem otevírá cestu od interpretace intencionality $\mathrm{k}$ výkladu jsoucího samého a jeho celku. Chceme-li však porozumět, jakým způsobem pro Patočku pojem ducha vyrůstá ze závěrů intencionální analýzy, musíme se nejprve obrátit k jeho předválečné přednášce Duch a dvě základní vrstvy intencionality.

Duchovní život je v této přednášce pojat jako modus vztahu aktové a horizontové intencionality, v němž se nejplněji uskutečňuje lidské bytí. ${ }^{32}$ Tento modus intencionality Patočka chápe jako usměrnění životní

28 Týž, Fenomenologické spisy, III/1, str. 176-183. Příležitostně Patočka označuje horizontovou intencionalitu dalšími výrazy, hovoří o ní jako o osobní, prožitkové či vnitřní, viz týž, Fenomenologické spisy, I, str. 290-298.

29 Týž, Fenomenologické spisy, III/1, str. 60 n.

30 Tamt., str. 179.

31 Týž, Fenomenologické spisy, I, str. 290-298.

32 Tamt., str. 290. 
spontaneity způsobem náležitým člověku. Zprvu a většinou tkví totiž výkon našeho života ve spontánním vyplňování možností naznačených v intencionálních horizontech. Toto netematické sepětí obou vrstev intencionality umožňuje bezprostřednost života: ustavuje jednotu subjektivního a objektivního, v níž se může život spontánně realizovat. Je to zajištěno možnostním charakterem horizontové intencionality, který znamená apriorní překlenutí distance, již každý intencionální akt rozevírá mezi naším prožíváním a syntetizovanými jsoucny. Možnosti obsažené v horizontové intencionalitě nicméně zprvu a většinou nejsou vlastními možnostmi konkrétního života: jsou to možnosti formované spontánně osvojenou tradicí. Do vztahu k této výchozí a v jisté míre nezbytné situaci našeho života klade nyní Patočka možnost ducha. Jejím nárokem je, že podstatou člověka není pouhá spontaneita, ale spontaneita ve formě svobody. Plné uplatnění svobody znamená spoluurčení celkové podmínky možnosti objektivace. ${ }^{33}$ Toho má být dosaženo tak, že se vědomě vztáhneme k celkovému významu našeho života a v rovině ideality mu udělíme ráz určitosti. Toto vědomé uchopení světa přitom prostupuje každý dílčí horizont a každou konkrétní možnost. Bytnost člověka tedy podle Patočky původně tkví ve specifickém modu předmětného vztahu, nikoli v netematickém a spontánním životě horizontového vědomí. Duchovní intencionalita je objektivním uchopením celkové možnosti lidského života a znamená její určité, leč nikoli definitivní vyplnění. Duch tudíž představuje specifický způsob objektivace, který život osvobozuje a v tomto smyslu oživuje, aniž by ho petrifikoval.

Z Patočkovy analýzy intencionálního života plyne, že duch je v jistém ohledu principem naší intencionality. Je jím jakožto úběžný bod veškeré lidské objektivující činnosti, jež člověka vždy staví do distance vůči ostatnímu jsoucímu, a tak jej individuuje a uschopňuje ke svobodě. Je jím, jinými slovy, jako účel, jehož dosažením se intencionální výkon člověka stává sebou samým a který po této stránce vymezuje podstatu člověka. Pojem ducha tak představuje klíčový aspekt poznání vztahu člověka a celku jsoucího. Představuje nicméně pouze jeden aspekt tohoto poznání, nebot' coby princip, jímž se člověk v celku jsoucího odlišuje, nemůže duch sám o sobě být východiskem pochopení toho, jak lidské bytí do tohoto celku patří. Proto s sebou nenese ani celkové porozumění lidskému životu, který jakožto život zprvu a většinou svobodný není. Duch je tedy principem našeho intencionálního života, ale pouze v omezeném smyslu: je tím, $\mathrm{k}$ čemu vposled směřuje veškeré naše předmětné úsilí, ale

33 Tamt., str. $296 \mathrm{n}$. 
není tímto úsilím samým co do jeho bytí, jeho „substance“. K této aporii ve svém závěru poukazuje přednáška Duch a dvě vrstvy intencionality, manuskript Nitro a duch od této aporie naopak vychází; rukopis tedy předpokládá závěry přednášky a klade si otázku, co je onen intencionální život, který má být zduchovněn, jinak řečeno, co je podstatou ducha. ${ }^{34}$

Cílem rukopisu Nitro a duch je nalezení deskriptivního sebepoznání, které lze učinit východiskem metafyziky. Zaujímá tedy střední místo mezi intencionální analýzou a metafyzickým výkladem jsoucího a jeho celku. Záměrem první části tohoto rukopisu je vyložit lidskou intencionalitu, konkrétně vymezit ontologický princip a účel objektivujícího aktu. Jsoucno je pak v souladu s cílem rukopisu tematizováno pouze jako intencionální korelát. Patočkovou tezí je, že principem vycházení našeho života ze sebe je jeho bytostný vztah k sobě samému, jímž se konstituuje individuální bytí. Jaké ontologické implikace tento popis objektivujícího aktu obsahuje?

Intencionální vycházení bytí ze sebe předpokládá apriorní cíl, který však nemůže mít charakter objektivity o sobě, protože uskutečněním intence je předmětnost teprve konstituována. Cíl našeho nepředmětného bytí tedy tkví v určitém ohledu v něm samém. Nepředmětné bytí na druhou stranu nemůže být cílem intencionálního aktu jednoduše jakožto nepředmětné, nebot' akt by je musel zpředmětnit, takže by je nedosáhl vůbec. Nepředmětné bytí tudíž předpokládá něco předmětného mimo sebe, čím současně samo určitým způsobem je. V tomto vztahu k subjektu stojí objekt, chápeme-li jej spolu s Patočkou jako zpředmětnění původně nepředmětného bytí, totiž jako výsledek syntetického aktu a zároveň prostředek, díky němuž se může nepředmětné bytí vztahovat $\mathrm{k}$ sobě samému - teprve médium předmětnosti dává totiž nepředmětnému sebevztahu obsah. Jelikož se nepředmětné bytí vztahuje samo k sobě, vystupuje ze sebe ven, tj. má intencionální charakter. Subjektivní a objektivní pól intencionálního aktu jsou tedy nutnými koreláty.

Výklad intencionality představuje lidské bytí jako takové bytí, které nemůže existovat jinak než skrze objektivaci v předmětném světě. V tomto smyslu je ukazuje jako bytí konečné. Intencionální akt je na jedné straně projevem nezbytnosti lidského bytí zachytit se v objektivnu, a tím vyplnit potencialitu obsaženou v intencionálním horizontu, tedy původní negativitu, která vyznačuje lidské bytí. Na druhé straně je intencionální akt současně projevem pozitivity, již představuje duchovní princip intencionality: akt je vyjádřením tíhnutí k objektivaci, $\mathrm{k}$ určitému

34 J. Patočka, Fenomenologické spisy, III/1, str. 17. 
bytí, a to v př́ípadě člověka znamená bytí individuálnímu. Dvojklaný vztah k sobě samému Patočka označuje jako „zájem“ bytí o toto bytí samo, tedy o to bytí, jímž zájem ve vlastním smyslu sám jest. ${ }^{35}$ Zájem je vztah „uvnitř““ jsoucího, kterým je určité bytí k sobě samému poutáno. Toto pouto konstituuje nepředmětnou jednotu individuálního bytí a její objektivní korelát, jenž má jednotu pouze jakožto syntéza. Tento vzájemně propojený pohyb zvnitřnění a zvnějšnění bytí označuje Studie jako „nitro“" a „výraz". 36

Závěr první části rukopisu Nitro a duch zní, že podstatou ducha je bytostný zájem. Postupem, jejž bychom mohli nazvat ontologií intencionálního aktu, Patočka dokazuje, že principem a účelem intencionality je vposled osobní bytí. Tento krok dává zjištěním intencionální analýzy individuální rozměr, k němuž poukazoval již pojem ducha, který však sám o sobě neumožňoval jeho objasnění. - Shrneme-li dosavadní postup za pomoci Patočkova rozlišení subjektivní a objektivní filosofie, mủžeme říci, že ontologie intencionálního aktu vede $\mathrm{k}$ jasnějšímu vymezení subjektivní stránky filosofie. Tento postup je však omezen pojetím jsoucna jako lidského intencionálního korelátu, a proto sám o sobě nedovoluje rozpracování její objektivní stránky.

4.

Výše jsme viděli, že omezení poznání jednoho pólu filosofie se podle Patočky promítá i do možnosti porozumět pólu druhému. V tomto př́ipadě se to týká poznání pojmu bytostného zájmu. Pojem zájmu vyjasňuje podstatně individuální založení intencionality, ale současně s sebou nese novou aporii. Bytostný zájem totiž sám o sobě není individuálním výkonem. Zájem našeho bytí o toto bytí samo v jistém ohledu přesahuje sféru našeho života: je mimo naše možnosti, protože z něho všechny možnosti pramení. Tato skutečnost souvisí s tím, že vztah zájmu je bytím či „substancí“ člověka, ale nikoli jeho bytností. ${ }^{37}$ - Jedná se o paradox, s nímž jsme se setkali již v případě horizontového vědomí. Také podstata tohoto vědomí není pro deskriptivní analýzu pochopitelná. ${ }^{38}$

\footnotetext{
35 Tamt.

36 Tamt., str. 98.

37 Tamt., str. 16. Srv. také tamt., str. 99-106. Patočka v tomto kontextu dává pojem substance do uvozovek.

38 Tamt., str. $53 \mathrm{n}$.
} 
Tento fakt v důsledku ukazuje, že ani deskriptivní analýza, ani ontologie intencionálního aktu nemohou být poznáním celku lidského života, respektive celku světa.

Cesta sebepoznání zde dochází do bodu, od něhož už nelze jít dál do nitra; pokračovat odtud v sebepoznání znamená podle rukopisů vydat se jaksi opačným směrem, k objektivitě. Přesněji řečeno k objektivitě pochopené v souladu se zjištěními deskriptivní analýzy, tedy k objektu ve smyslu předmětné syntézy určitého vztahu bytí k sobě samému. Tento obrat k objektu není zaměřen pouze na předmětnost $\mathrm{v}$ její jednotlivosti, nýbrž, jak to ohlásil rukopis Úvod, primárně na předmětný svět jako celek, který je rámcem lidského života. Patočka jej provádí způsobem, který naznačil v uvedení rukopisů: sebepoznání ve smyslu poznání intencionálního výkonu chce překročit na jeho vlastním základě. Postup je následující: předmětnost nejprve tematizuje ve vztahu k prožívání. Protože však popis způsobu, jakým se nám jsoucno ukazuje, odhaluje pouze jeho bytí o sobě jakožto jeho bytí pro nás, činí následně Patočka metafyzické gesto, $v$ němž na podkladě závěrů deskriptivní analýzy spekulativně určuje podstatu jsoucna jako takového. Nakonec oběma krokům podkládá společný fundament, tj. určuje jednotu subjektu a objektu v metafyzickém smyslu slova.

Poznávání jsoucna o sobě začíná poznáním jeho bytí pro nás; východiskem vlastního výkladu předmětnosti má být popis základního způsobu, jak se nám jsoucno jeví, to znamená způsobu, který v našem prožívání jaksi nese všechny ostatní způsoby jeho zjevnosti. Poznávání objektivity je tedy v prvním kroku prostým rozvinutím intencionální analýzy, tentokrát s důrazem na předmětný pól. - Zkoumání intencionality nás přivedlo k závěru, že zájem individuálního bytí o toto bytí samo je možný jen tehdy, opírá-li se o konkrétní předmětnost. V souladu s tím je náš život vždy již do jisté míry odpovědí na vnímaný svět. Apriorní odpovědí našeho života je horizontové vědomí, které vymezuje, co se vůbec jeví jakožto možné. Konkrétně je to horizont těla, co nás vřazuje mezi věci, a to nikoli předmětně, nýbrž prostřednictvím nálad, v nichž rozlišení subjektu a objektu do značné míry splývá. ${ }^{39} \mathrm{~V}$ náladách prožíváme předmětný svět jako svět smyslových kvalit a z nich sestávajících celků, na které se vždy již spontánně ladíme. Tím je dán podklad, na němž je teprve možné pojmout vnímané jako objektivní substance, a tedy jako prostředky či pouhé věci. ${ }^{40}$ Původním vztahem člověka ke

\footnotetext{
39 Tamt., str. 108.

40 Tamt., str. 53, 61 a 97-99.
} 
smyslové rozmanitosti je tudíž vztah vyjadřování vnímaného v lidských možnostech. Smyslové okolí náš život bud’ jistým způsobem omezuje, anebo jej k jeho možnostem uvolňuje - je tomu tak proto, že náš životní pohyb vstupuje do souladu, anebo disharmonie s dynamikou vnímanou ve smyslové rozmanitosti. Deskriptivní analýza tedy ukazuje, že na základní úrovni zakoušíme vnímané jsoucno jako fenomén svébytného pohybu, a to podle Patočky znamená jako fenomén života. Život jsoucna coby korelát našeho naladění tímto způsobem zakoušíme stále, avšak na našem naladění je vždy již vybudován složitější intencionální akt, jímž je význam této základní vrstvy zastřen. V důsledku toho spatřujeme jsoucno předně jako moment praktické orientace vlastního zaujatého života a již skrz ně zpravidla nepronikáme $\mathrm{k}$ jeho bytí, totiž k životu.

Základní způsob lidského vnímání ale nekonstituuje praktickou stránku jsoucen, nýbrž nechává promluvit jejich vlastní podstatu v médiu nálad. V naladění není ustavena předmětnost, a tedy ani ontologický rozdíl mezi vnímajícím a vnímaným; teprve díky této prvotní jednotě s životem jsoucího je jaksi v druhém kroku umožněn předmětný vztah. Popisem naladění lze tedy $\mathrm{v}$ préedmětném pólu intencionálního aktu objevit jistý život, který není výsledkem intencionální syntézy, ale její podmínkou. ${ }^{41}$ Patočkovým dalším krokem je přechod od popisu zkušenosti k metafyzickému pojmu života coby principu predmětnosti a k pojmu objektivace jakožto životnímu procesu. Postup strahovských systematických rukopisů od deskriptivní fenomenologie k fenomenologicky koncipované metafyzice však představuje specifický výkladový problém, jelikož způsob přechodu v nich není prakticky vůbec probírán. V této souvislosti se přitom kladou závažné otázky týkající se toho, jakou roli má metafyzická spekulace přidělit závěrům konstitutivní analýzy a zkušenostní variace a jakým způsobem je má dále rozvinout.

Výslovnou, byt' značně stručnou reflexi tohoto kroku najdeme pouze v manuskriptu Studie k pojmu světa, tentokrát jako přechod mezi deskripcí a „fenomenologickou explikací“. ${ }^{2}$ Vezmeme-li v úvahu konkrétní vyjádření Studie, jakož i její celkové směřování, lze formulovat hypotézu, že fenomenologickou explikací Patočka rozumí korigované rozšsiření „základní struktury možné subjektivity“ neboli principů lidského bytí, jež objevila intencionální analýza, na ostatní individuální jsoucna a vposled na bytí jako takové. Přesněji vzato je explikace určením míry a způsobu této generalizace, které se má řídit tím, jak se nám interpretované bytí

41 Tamt., str. 99.

42 Tamt., str. 97 n. Srv. také Patočkovo provedení explikace, např. str. 106-108. 
jeví. Účelem a zároveň kritériem metafyzické spekulace má pak být pochopení popsané zkušenosti - zcela nesmyslná zkušenost se Patočkovi v této souvislosti patrně jeví jako něco podstatně nemožného. ${ }^{43}$ Obecná teze fenomenologické explikace zní, že podobně jako člověk je každé $\mathrm{k}$ individualitě směřující jsoucno ve své podstatě dvěma protikladnými pohyby, totiž vztažením se k sobě a vystoupením ze sebe ven neboli zniterněním a zvnějšněním. Patočka tyto pohyby terminologicky fixuje jako „nitro“ a „výraz“. Pohyb zniternění znamená, že bytí jsoucího je nepředmětnou jednotou: je vztahem k sobě samému, který ovšem nutně směřuje vně sebe. Pohyb zvnějšnění pak znamená, že bytí je principem předmětné jednoty: je vždy již vztaženo k předmětnosti a samo do ní vstupuje. Pohyb zniternění a v něm založený pohyb zvnějšnění tak tvoří základní strukturu bytí konečného a v tomto smyslu individuálního jsoucna; každé specifické individuální jsoucno je těmito pohyby tak, jak to odpovídá jeho způsobu bytí a jak je to zjevné v naší zkušenosti. Odlišné ontologické pojetí, podle něhož by bytí bylo ryzí niterností anebo jsoucno pouhou vnějšností, podle Patočky není možné konsekventně myslet. ${ }^{44}$

Charakteristickým rysem Patočkovy teze o struktuře nitra je, že je současně tezí o podstatě individuálního jsoucna i o jednotném vztahu jsoucen pojatém jako intersubjektivita. Z rukopisů vyplývá, že pohyb bytostného zájmu ze sebe ven do předmětného světa je vždy zároveň vztahem k druhému životu. Jestliže totiž v každé předmětnosti, s níž se lze setkat, je obsaženo zvnějšňující se nitro, je veškerý kontakt v oblasti objektivna vždy také vztahem v oblasti subjektivna. Jinými slovy, individuální bytí je vždy již spolubytím ve zcela konkrétním slova smyslu, totiž jako skutečný kontakt života s životem. Sebeobjektivace i objektivace jsou v případě individuálních niter tvořeny souhrou dvou životních pohybů: výraz zvnějšňujícího se nitra krystalizuje ve vědomém nebo analogickém intencionálním vztahu nitra vnímajícího. Individuální nitra však zároveň netvoří ontologické médium svého vlastního setkání, jak je zjevné z toho, že svou vlastní objektivaci ani objektivaci druhého neprožíváme. Struktura nitra zde prostřednictvím intersubjektivity poukazuje opět do sféry podmínek individuálního výkonu.

Médiem, skrze něž se jedno nitro vztahuje k druhému, je podle Patočky elementární, ne-individuální rovina předmětnosti. Do ní spadá i naše tělo v té mîre, v níž není nikdy v plném slova smyslu osobní. V této matérii se jedno nitro projevuje a k ní se druhé nitro vztahuje, nakolik

43 Tamt., str. $98 \mathrm{n}$.

44 Tamt., str. 100. 
je objektivujícího vztahu schopno. Patočka ji v návaznosti na Husserla nazývá „hyletickou rozmanitostí“ či „hyletickou vrstvou“. Platí sice, jak jsme výše viděli, že předmětnost je objektivací a sebeobjektivací individuální niternosti, či přesněji zachycením jednoho života v druhém, ale platí to pouze do jisté míry. ${ }^{45}$ Nakolik totiž individuální subjektivity nejsou principem vlastní objektivace a samého bytí předmětné matérie, natolik je předmětnost něčím od nich odlišným. ${ }^{46} \mathrm{~V}$ souladu s Patočkovým fenomenologickým výkladem je i tato ne-individuální objektivace neboli hyletická vrstva zpředmětněním jistého života. Tento život Patočka v závěru fenomenologické explikace určuje jako nikoli individuální život, který a priori propojuje individuální bytosti na předmětné i nepředmětné rovině, a tvoří tak hlubší jednotu jsoucího. ${ }^{47}$

Cesta k poznání ne-individuální jednoty života vede skrze pochopení postupného oslabování individuality u veškerého mimo-lidského bytí čili ostatních forem niternosti. Klíčem k pochopení těchto životních forem, jakož i jednoty všeho živého je interpretace dvou základních vrstev intencionality. Patočka ukazuje, že ostatní formy niternosti můžeme poznat, pokud v pojmu konstituce lidské zkušenosti provedeme určité restrikce, které korespondují s výrazem těchto forem v naší zkušenosti, přičemž z oslabení individuálních stránek intencionality vždy vyplyne posílení stránek jiných. ${ }^{48}$ Vztah zvîrete a rostliny navenek tak Patočka chápe jako zjednodušený modus lidské duchovní intencionality, tj. vztahu uchopujícího jsoucí v jeho celku. Předmětné uchopení je u těchto bytostí oslabeno a nahrazeno pevnějším spontánním zapojením do celku přírody, které vykonává schopnost analogická horizontové intencionalitě, jakou je kupř. instinkt. ${ }^{49}$ Nejjednodušší, a tudíž nejméně individuální

45 Tamt., str. 108.

46 Ačkoli výklad „hyletické vrstvy“ se v $\$ 14$ Studie k pojmu světa zdá být uzavřen, v $§ 15$ se dozvídáme, že podstata této vrstvy zůstává neurčena.

47 Tamt., str. $60 \mathrm{n}$. Viz též předchozí poznámku.

48 Tamt., str. 54. Patočka zde přejímá a parafrázuje Heideggerův návrh ,privativní interpretace života“ z $\$ 10$ Bytí a času.

49 J. Patočka, Fenomenologické spisy, III/1, str. 107. Opačnou perspektivu popisované geneze viz tamt., str. 63: „,.., horizontová‘ intencionalita emocionálnúho prožívání ustupuje výslovné ,aktové‘, do níž se vkládá výslovné fiat našeho já.“ 
formou niternosti je nepředmětná příroda, jež se jeví jako hmota či energie čili jako „př́roda anorganická“. V této niternosti je odlišnost mezi intendujícím a intendovaným, stejně jako diference mezi individuálním a neindividuálním zcela oslabena. Nepředmětná příroda je nejsilnější možnou jednotou niternosti a vnějšnosti, subjektivního a objektivního, takže „mínění“ je pro ni vždy již „,vyplnění“ a veškerý její pohyb se děje bez úsilí charakterizujícího život individuální. ${ }^{50}$

Patočka, jak uvidíme, chápe nepředmětnou přírodu jako život, který je co do svého bytí rovněž specifickým vztahem k sobě samému. Ne-individuální život přírody však nevyvěrá z rozlišení vnitřku a vnějšku, jež charakterizuje individuální bytosti, jinými slovy z distinkce, kterou jsme dosud poznali jako základní tezi Patočkovy spekulativní metafyziky. Z důvodu této současné spřízněnosti s jednotlivým a odlišnosti vǔči němu prŕíroda př̌konává rozdělení veškerého individuálního života i vší předmětnosti, takže působí jako vnitřní jednotící prvek celku jsoucího. Jako taková je universálním životem, který vždy již zpředmětňujeme v podobě anorganické př́írody. Má-li však být jednotou živé rozmanitosti, musí v sobě protiklad nitra a vnějšku nějakým způsobem obsahovat. Pokusíme se ukázat, že příroda v sobě podle Patočky obsahuje protiklad subjektu a objektu v podobě rozporu nevědomé jednoty jsoucího a vědomí individuality, který je počátkem individuální niternosti a vposled pramenem života jako takového. Takto Patočka interpretuje poslední mez zkušenosti, která v jistém smyslu spočívá v jejím samém středu. Z Patočkova hlediska je přitom bytí přírody třeba vyložit do té míry, abychom v něm mohli vlastní život zakládat v souladu s povahou našeho skutečného spočívání v něm, tj. co do naší jednoty s ním a odlišnosti vůči němu.

Jakožto jednota nitra a vnějšku příroda překračuje všechny hranice ve jsoucím a spojuje jednotlivé na všech úrovních objektivity i subjektivity. ${ }^{51}$ Příroda takto není něčím vnějším, není jednotou ve vlastním smyslu vztaženou vůči jednotlivému či od něj oddělenou, nýbrž je inherentní podmínkou každého vztahu v jednotlivém. V jednom ohledu je tím rozměrem niternosti, jenž každou bytost aktivně zapojuje do celku jsoucího: je veškerou spontaneitou a pasivitou jednotlivého, činného života. V této

50 Tamt., str. 60-64, 105 n., 110-112. Důsledně vzato není př́íroda ani výrazem ani nitrem - přinejmenším v tom smyslu jako nitra jednotlivá -, protože tento rozdíl překlenuje. V jiném smyslu platí, že je obojím. Vysvětlíme to níže. Patočka přírodě nitro přisuzuje, srv. tamt., str. $111 \mathrm{n}$.

51 Tamt., str. 61-63. 
podobě je příroda životem našeho těla, instinktem, horizontovým vědomím, jakož i zájmem bytí o toto bytí samo. Jinými slovy, příroda je vším tím, co je nám nezrušitelně dáno jako vnitřní podmínka žití, je pro nás něčím intimním, a zároveň cizím. $\mathrm{V}$ druhém ohledu je příroda podkladem vystupování jednotlivého života ze sebe. Příroda je v této podobě spontaneitou hyletické vrstvy, jež nese zvnějšňující se individuální život: je nepředmětným rozměrem předmětného, nerozlišeností předmětnosti a nepředmětnosti, jež tvoří pozadí objektivace, to znamená světlem, teplem a ostatními živly, jakož i volným pohybem..$^{52}$

Život sjednocující přírody je nevyčerpatelný a postupuje bez překážek; nepozorujeme v něm konečnost individuálního výkonu bytí ani svobodu, nýbrž nekonečnou nutnost, která se může jevit až jako životu protikladná. V čem spočívá vnitřní život přírody a jak z něho povstává náš život? Spekulativní odpověd’ na tyto otázky buduje Patočka rovněž na podkladě spojení analýzy lidského prožívání a interpretace způsobu, jakým se nám příroda sama jeví; výklad její vnitřní dynamiky a geneze intencionality zakládá na popisu zcela pasivních, neosobních momentů našeho intencionálního života, jako je zapomínání, spánek a snění, což jsou zároveň momenty, jimiž se individuum udržuje a obnovuje, které mu dávají život tím, že v něm duchovní a vědomý život oslabují. ${ }^{53}$

Vztažení přírody k sobě je to, co uvádí všechna jednotlivá nitra, jejich kontakt a konflikt, jakož i celý kosmos do základního souladu. Po této stránce Patočka pravděpodobně interpretuje pohyb př́rody na základě analogie s bytostným zájmem, jímž se individuum vztahuje zároveň k sobě, a tím i k určité předmětnosti a jinému životu v ní. Tíhnutí prrírody $\mathrm{k}$ jednotě je však zároveň něčím právě opačným vůči individuálnímu zaujetí vlastním bytím, které se musí zachytit v něčem jiném - příroda $\mathrm{v}$ tomto ohledu směřuje k sobě pouze skrze sebe samu. Co je tedy smyslem jejího pohybu, je-li tento pohyb osmyslitelný?

Patočka požaduje, aby osmyslitelný byl. Skutečnost, že př́roda se jeví jako bytostný pohyb, ukazuje, že je nadána určitým bytostným nedostatkem. Př́roda je sice nerozlišeností subjektu a objektu, nikoli však jejich identitou, takže je nadána sobě vlastní dynamikou. Negativita, jíž př́roda je, je podle Patočky nakonec negací její vlastní nerozlišenosti: příroda tíhne ke svému protikladu, $\mathrm{k}$ naprosté individuaci, $\mathrm{k}$ úplnému sebevědomí, jimiž ze své podstaty je, nebot' jako příroda je vůbec vším. ${ }^{54}$

\footnotetext{
52 Tamt., str. 95-97, 99.

53 Tamt., str. 110-112.

54 Tamt., str. 112.
} 
Plné sebevědomí, jež znamená dokonalé vydělení se v rámci prŕírody, označuje Patočka výrazem „Bůh“. Z tohoto pojetí plyne, že život je bytí přírody, protože prríroda je původně pohybem směrem k vědomí coby svému vnitřnímu určení. Vědomí tak představuje prvotní rozpor v životě jako takovém. V tomto smyslu je vědomí principem individuace přírody, který ve specifickém stupni náleží každé formě niternosti, tak jako člověku náleží duch: „Rostlina je ještě snící, zvî̃e počínající, člověk částečné, Bůh totální setkání se sebou. "55 Příroda jako taková se ovšem ve vlastním smyslu individuovat nemůže, může se zkonečnit pouze jakožto něco jiného, tj. pouze ve formě niternosti a vnějšnosti. Její slepé tíhnutí k vědomí je skutečné, avšak nenaplnitelné. Proto Patočka interpretuje život prrírody jako život melancholický či bolestný, nebot' tento život se nemůže stát sebou samým. A proto jej zároveň vykládá jako život snící a zapomínající: nekonečná spontaneita přírody je totiž aktivitou, v níž „subjekt“ tvoří „objekt", který je od něj nerozlišitelný, a je tedy obdobou snění; snění přírody jako celku pak sice tíhne k bdění, ale nikdy k němu nedospívá, nemůže samo sebe apercipovat, a tak se podobá nekonečnému zapomenutí. ${ }^{56}$

V tomto smyslu příroda obsahuje sebevědomí a má coby základní ontologická nerozlišenost i subjektivní charakter, vymezujeme-li ho na základě pojmu vědomí. Strahovské rukopisy ale pojímají subjektivitu v širším smyslu, totiž v podobě před-reflexivního sebevztahu, jenž k vědomí směřje, neboli jako nitro ${ }^{57}$ - snad proto Patočka říká, že ,zapomnění na sebe není absence jednoty, absence já“ “. ${ }^{8} \mathrm{Z}$ hlediska tohoto významu pojmu subjektu je filosofický systém, jejž Patočka různými způsoby rozpracoval ve strahovských rukopisech, snahou o uskutečnění programu z epilogu Přirozeného světa, totiž výkladem bytí jakožto konstitutivní činnosti na podkladě poznání základních struktur možné subjektivity.

V pojmu př́rody shledáváme fundament Patočkova programu spojit subjektivní a objektivní filosofii, resp. učinit subjektivní základem objektivního. Příroda tíhnoucí k vědomí je dvojznačná, je radostí života, spontaneity i svobody, a je též jeho slepotou a nahodilostí. Člověk se podle Patočky má ve vztahu k této dvojznačnosti rozpoznat jako svobodná bytost, avšak nemá a ve vlastním smyslu nemůže se v něm rozpoznat jako bytost odloučená, nebot' jeho svoboda je vposled svobodou

\footnotetext{
55 Tamt., str. 111.

56 Tamt.

57 Tamt., str. 55.

58 Tamt., str. 111.
} 
osvobozené přírody. Stát se sebou samým zde pro Patočku znamená stát se individuální součástí universálního živého celku, celku, v němž jsou všechna jednotlivá jsoucna spojena jednotou rozporného bytí přírody a v souladu s touto dvojznačností mají realizovat svou individualitu. Př́́roda podle Patočky znamená možnost smysluplnosti v lidském životě. Současně však znamená, že jakkoli svobodný člověk bude, bude vždy zároveň bytostně slepý, protože taková je jeho bytnost, protože takové je bytí samo.

6.

V době vzniku strahovských rukopisů tvoří ontologický pojem přírody nedílnou součást Patočkova filosofického stanoviska. Toto zjištění nápadně kontrastuje se skutečností, že tento pojem nesehrává výraznější roli v Patočkově pozdější tvorbě. Záhy po zastavení prací na strahovském rukopisném projektu píše Patočka stat'Věčnost a dějinnost, v níž vymezuje prŕrodu jako jeden z význačných horizontů lidského života, ale již nikoli jako bytí jsoucího. ${ }^{59}$ Máme zde tedy co do činění s jednou z proměn $\mathrm{v}$ mnoha ohledech dosud nepříliš známého Patočkova filosofického vývoje. Se snahou porozumět této proměně se pojí otázky, proč Patočka svou velkoryse rozvrženou koncepci v určité chvíli odložil a zda tato koncepce může být v nějakém ohledu živá pro nás. Další výklad strahovského filosofického projektu, jenž bude na tyto otázky s to navrhnout odpověd', vyžaduje bližší pochopení samé myšlenky pojmout přírodu jako nepředmětné bytí jsoucna. Ke zmapování možností tohoto pojetí ontologie chceme přispět srovnáním Patočkovy filosofie s fenomenologickým pojetím přírody jako bytí jsoucího u Maurice Merleau-Pontyho. Na základě tohoto srovnání se nakonec pokusíme ukázat originální stránky a meze stanovisek obou autorů.

Merleau-Ponty rozvíjí myšlenku ontologie založené na pojmu přírody od poloviny padesátých let až do své smrti. Srovnáme-li vyjádření obou autorů, ukazuje se, že jejich výklad přírody, již bychom spolu s Patočkou mohli nazvat „nepředmětnou“, vychází v převážné míre ze shodných předpokladů a dochází $\mathrm{k}$ podobným závěrům. Odlišnost obou koncepcí je vedle částečně odlišných východisek dána především rozdílnou celkovou představou, čeho má filosofie za pomoci ontologie přírody dosáhnout. V následujícím kroku se proto pokusíme shrnout, v čem spočívá

59 J. Patočka, Věčnost a dějinnost, in: týž, Péče o duši, I, kap. 14. 
Merleau-Pontyho motivace vybudovat fenomenologicky pojatou ontologii přírody, a stručně vyložit, jak její pojem koncipuje.

Merleau-Pontyho myšlenkový vývoj charakterizuje snaha o překonání dualismu subjektu a objektu v našem přístupu k bezprostřednímu prožívání a v pojmovém uchopování světa. Koncept před-objektivní „primordiální přírody“ představuje u Merleau-Pontyho padesátých let pokus, jak sjednotit jistou dvojitost obsaženou v jeho vlastním dosavadním myšlení, jakož i v tradici, z níž vychází, totiž dualitu významu a skutečnosti. Tato dualita u něj vyrůstá z koncepce perceptivního vědomí rozvržené ve Fenomenologii vnímání. Ve své následující tvorbě Merleau-Ponty pojem perceptivního vědomí dále rozvíjí, další vývoj tohoto pojmu je však spojen s podstatným přepracováním jeho obsahu. Vymezení obsažené ve Fenomenologii vnímání je totiž podle Merleau-Pontyho natolik spjato s filosofií vědomí, že stále předpokládá ontologický rozdíl mezi subjektem a objektem. ${ }^{60}$

Přepracované pojetí vnímání nacházíme $\mathrm{v}$ přednáškovém cyklu z roku 1953 Smyslový svět a svět vyjadřování. ${ }^{61}$ Vztah odkázanosti vtěleného vědomí na vnímatelný svět, jakož i vztah odkázanosti tohoto světa na vědomí zde Merleau-Ponty vymezuje jako vztah vyjadřování, resp. výrazu. Vtělené perceptivní vědomí neuchopuje svůj předmět přímo, nýbrž je samo součástí vnímatelného světa a dosahuje perspektivy předmětu v koordinaci s možnostmi, které mu svět předkládá. Bytí subjektu v sobě v tomto smyslu vyjadřuje vnímané a vnímané v něm dospívá ke svému výrazu. ${ }^{62}$ Tělesný svět se ve vnímajícím těle rozvíjí jako jistý životní rytmus, jenž má charakter subjektivních možností určitým způsobem být. Tato myšlenka odpovídá jedné polovině teze o vnímání, již nacházíme v Patočkových strahovských rukopisech. Ačkoli Merleau-Ponty myslí vnímané na základě jednoty subjektu a objektu, nejde v daném období tak daleko, aby souhlasně s Patočkou prohlásil, že také vnímané ve svém bytí vyjadřuje vnímajícího. V přednáškách Smyslový svět a svět vyjadřování neurčuje vnímatelné jako odkázané na vnímajícího co do svého bytí, ale pouze co do svého výrazu. Vnímání, resp. jednotu subjektu a objektu, totiž myslí ze vztahu k vnímajícímu.

60 Srv. začátek přednášek z roku 1953: M. Merleau-Ponty, Le monde sensible et le monde de l'expression. Cours au Collège de France. Notes, 1953, Genève 2011.

61 Tamt., str. 49. Viz také M. Merleau-Ponty, Řě̌, dějinnost, příroda. Shrnutí přednášek z Collège de France (1952-1960), přel. J. Halák, Praha 2018, str. 9-15.

62 Srv. J. Halák, „Vnímání je již vyjadřování“. Merleau-Pontyho první přednášky na Collège de France, in: Reflexe, 52, 2017, str. 111-135, cit. str. 113-115. 
Merleau-Pontyho práce z padesátých let, jako jsou přednášky o přírodě, stat' Filosof a jeho stín či rukopisné fragmenty Koncept $k$ Viditelnému a neviditelnému a Př́roda neboli svět ticha, ukazují, že se pokusil dvojitost významu a skutečnosti převést na společný základ koncipovaný jako ontologický pojem přírody. ${ }^{63}$ Tento záměr vychází zčásti z Merleau-Pontyho interpretací dobových poznatků přírodních věd, které předložil během tříletého cyklu přednášek o přírodě. Obecným závěrem těchto interpretací je, že poznatky soudobé vědy ukazují, v protikladu $\mathrm{k}$ dosud převládajícímu objektivismu $\mathrm{v}$ přírodních vědách, podstatnou vzájemnou provázanost jednotlivých momentů a částí jsoucího. ${ }^{64}$ Tuto skutečnost názorně ilustruje Merleau-Pontyho pojem interanimality. ${ }^{65}$ Podle tohoto konceptu není bytí organismu definováno pouze vnitřním morfo-genetickým utvářením, ale i ontickými vztahy s živým i neživým okolím. V prrípadě živé prírody tedy neplatí pouze, že organismus vyjadřuje vnímané okolí ve svých životních možnostech, jak to Merleau-Ponty předpokládal v roce 1953, ale samo jeho bytí je výrazem jeho okolí a bytí tohoto okolí v sobě zas vyjadřuje tento organismus. V těchto interpretacích se jeho závěry sbíhají s Patočkovými tezemi o provázanosti individuální niternosti. Ve svém úhrnu poukazují Merleau-Pontyho interpretace přírodovědeckých poznatků k obecné ontologické tezi. $\mathrm{K}$ její formulaci nepřistupuje Merleau-Ponty přímo, nýbrž pokouší se pro ni v první části prvního přednáškového cyklu vymezit pole pomocí kritické i souhlasné interpretace autorů, jejichž pojímání přírody se mu jeví klíčové pro moderní dobu. ${ }^{66}$ Jako možné východisko ontologického pojetí vzájemných vztahů jsoucího pak navrhuje zvolit Schellingovu filosofii přírody.

Merleau-Pontyho výklad Schellingova chápání přírody vyrůstá z opozice, již Merleau-Ponty konstruuje mezi karteziánskou koncepcí přírody a pojetím romantickým, do něhož vedle Schellinga překvapivě řadí také Bergsona a Husserla. Zatímco Descartes z Merleau-Pontyho hlediska usiluje o uchopení př́rody jako objektu nekonečně rozděleného a vněj-

63 R. Barbaras, Merleau-Ponty and Nature, in: Research in Phenomenology, 31, 2001, str. 22-38, cit. str. 26.

64 Srv. zejm. M. Merleau-Ponty, La Nature. Notes. Cours du Collège de France, Paris 1995, str. 187-259; týž, Řeč, dějinnost, př́roda, str. 72-76.

65 M. Týž, La Nature, str. 247-248; týž, Řeč, dějinnost, př́roda, str. 74.

66 Merleau-Pontym nepublikované přednášky o prŕrodě představují patrně nejrozsáhlejší dokument jeho uvažování o prrírodě, jsou však problematickým pramenem, nebot' autorovy vlastní teze v nich nejsou vyjádřeny přímo, nýbrž spíše nerozlišitelně splývají s jeho interpretacemi jiných autorů. 
šího vůči subjektu, romanticky smýšlející autory podle něj spojuje snaha chápat př́rodu jako to, co předchází objektivnímu bytí a utváří niterný život člověka. Mezi obě antagonická stanoviska klade konečně Merleau-Ponty Kantovo humanistické myšlení, v němž zvnitřnění prrírody člověkem ústí v její opětovné zpředmětnění; Kantova úvaha o absolutním základu ale podle něho měla sloužit jako východisko pro Schellingovo uchopení romantického pojmu přírody.

Kant otevírá možnost myslet přírodu jako autonomní bytí, když kritizuje představu pozitivně pojatého absolutního základu, z něhož theologicky orientované filosofie bytí přírody dedukují. Sama možnost myslet absolutno jako vždy dokonalejší podle Kanta odkazuje k jakémusi závratnému nekonečnu, jež veškerou předmětně pojatou dokonalost překračuje. - Kantem ale i jinými inspirovaný pojem „,bezedna“ coby ryze nepředmětného absolutna se stává východiskem Schellingovy filosofie. ${ }^{67}$ Umožňuje mu totiž myslet ničím neomezenou spontaneitu, která je předpokladem skutečné jednoty a zároveň dějinnosti jsoucího. Toto ontologické pojetí jednoty, která je současně neustávajícím pohybem, upoutalo i pozornost Merleau-Pontyho. Jeho interpretace je vedena myšlenkou, že Schellingova filosofie prŕrody představuje specifickou koncepci bytí, která není zatížena dualistickými implikacemi. Schelling podle něj chápe př́rodu jako nekonečné bytí, které má charakter nevyčerpatelné spontaneity. Nekonečná spontaneita není omezena žádnými určeními mimo sám charakter absolutně spontánního dění. ${ }^{68}$ Jakožto o sobě neomezená vstupuje spontaneita přírody nutně do svého výrazu, který má charakter objektivovatelných jsoucen. Aby se konečně mohla $\mathrm{v}$ podobě jsoucna objektivovat, musí se prríroda nejprve zkonečnit co do bytí. V souladu s tím se příroda vstupující do výrazu zkonečňuje v rozmanitých podobách omezené spontaneity, jejichž úběžníkem je spontaneita $\mathrm{v}$ plném slova smyslu konečná, to znamená úplně individuovaná. ${ }^{69}$ Interakce všech instancí spontaneity se nakonec objektivuje jako vnímatelný svět.

Jelikož život př́rody nepramení z žádného daného základu, nebo jinak řečeno, poněvadž příroda je sebevyjadřováním samým, je jako taková ve svém zkonečnění zcela obsažena. Jednak tedy platí, že příroda je nekonečným principem konečného bytí, jakož i bytím vnímatelných jsoucen; jednak platí, že konečné bytí a vnímatelná jsoucna nejsou ničím

67 M. Merleau-Ponty, La Nature, str. 59-62.

68 Tamt., str. 61.

69 Tamt., str. 65. 
jiným než zkonečněním, totiž výrazem přírody. Tento aspekt Schellingovy koncepce je pro Merleau-Pontyho mimořádně důležitý, znamená totiž, že vztah výrazu a vyjadřovaného je v tomto pojetí důsledně reciproční. Z tohoto tvrzení plyne mimo jiné překvapivá myšlenka, že nejen vše konečné je výrazem nekonečna, ale i samo bytí přírody v sobě jaksi vyjadřuje spontaneitu individuálního života. ${ }^{70} \mathrm{Z}$ ontologie zkonečnělé nekonečné spontaneity vposled vyplývá, že bytí přírody ani příroda jakožto jednotlivé jsoucno nejsou dedukovatelné z absolutního principu. Život přírody jako celku tudíž není apriori ničím omezen a v tomto ohledu je životem v nejsilnějším možném slova smyslu..$^{71}$

Pohlédneme-li na Merleau-Pontyho interpretaci Schellingovy ontologie z perspektivy jeho vlastní fenomenologie vnímání, ukazuje se, že Schellingovo pojetí nekonečně spontánní přírody umožňuje myslet původní jednotu mezi prožíváním a skutečností, protože prríroda v tomto významu funduje rozlišení subjektu a objektu. Ze Schellingova pojetí Merleau-Ponty vyvozuje, že bytí vnímajícího i vnímaného je založeno na téže živé jednotě a že význam, který vnímající ve výraze přírody prožívá, je v ní jakožto nerozlišenosti subjektu a objektu jaksi zárodečně obsažen. ${ }^{72}$ Vnímání je tudíž nerozlišeností subjektu a objektu ve zkonečnělé podobě.

Vnímání konstituuje určitý základní jednotný vztah ve jsoucím, jednota sama ovšem může být prožívána různě, a to na základě toho, jak je chápána. Ze Schellingova pochopení lidské svobody vyplývá, že smyslová percepce má dějinný rozměr, který modifikuje naše prožívání, včetně prožívání jednoty jsoucího. Člověk osvícenské doby podle Schellinga není schopen zakoušet přírodní jednotu, protože jeho vnímání je deformované racionalistickým chápáním přírody. Toto hledisko hodlá Schelling, a v návaznosti na něj též Merleau-Ponty překonat filosofickou reflexí. Účel reflexe Merleau-Ponty odvozuje spolu se Schellingem z původní jednoty vnímání a vnímaného. Reflexi, jež sama o sobě nutně vede k rozpadu této jednoty, chce Schelling pojmout jako nástroj jejího znovuobjevení. Protože původní, před-objektivní příroda není jako taková poznatelná, má reflexe opět umožnit před-reflexivní vztah k př́rodě: má nám dovolit prožít ji v jejím nerozlišeném, „barbarském“ "bytí. ${ }^{73}$

70 Tamt., str. 61 a 68.

71 Tamt., str. 61.

72 Tamt., str. 62.

73 Tamt., str. $62 \mathrm{n}$. 
Merleau-Ponty ve svém výkladu patrně předpokládá, že distance vůči nerozlišenu, kterou reflexe zakládá, umožňuje svobodné jednání, jež vykračuje ze samopohybu přírody, a v důsledku toho je tímto pohybem vyjadřováno. To mu dovoluje tvrdit, že lidské dějiny vyrůstají z geneze prrírody a že bytí prrírody není vůči těmto dějinám lhostejné. Avšak v přednáškách o prrírodě Merleau-Ponty nevysvětluje, jakým způsobem pramení svoboda reflexe či jakýkoli jiný protiklad ve jsoucím z původní nerozlišenosti bytí. Nejbližším vysvětlením je v tomto ohledu Merleau-Pontyho naznačení, že příroda je v nějakém smyslu v sobě protikladná. ${ }^{74}$

Postoupíme-li ve vývoji Merleau-Pontyho myšlení ke stati Filosof a jeho stín, rukopisu Př́roda neboli svět ticha a k přípravným pracím k Viditelnému a neviditelnému, můžeme říci, že ontologické pojetí nalezené v Schellingově filosofii se Merleau-Ponty rozhodl učinit součástí vlastního filosofického stanoviska. Závěr stati Filosof a jeho stín určuje přírodu jako ten rozměr našeho bytí, který nelze pomocí fenomenologické metody pochopit přímo, avšak k němuž přesto musí fenomenologie nalézt určitý vztah jakožto ke své mezi. Tohoto úkolu se Merleau-Ponty do jisté míry ujal v publikované části rukopisu Př́roda neboli svět ticha ${ }^{75}$

Obsahem tohoto fragmentu je úvaha o pojmu bytí vystavěná jako kritika dualistické ontologie, již Merleau-Ponty přičítá karteziánsko-kantovské „filosofii subjektu“ a sartrovské „filosofii svobody“. Zaměřme se pouze na jeho výklad filosofie svobody. Ta podle Merleau-Pontyho pojímá subjektivní bytí jako negaci předmětného bytí, a předmětné bytí, včetně přírody, jakožto korelát subjektivity. V této souvislosti Merleau-Ponty znovu spojuje ontologii s tématem prožívaného smyslu a dovozuje, že pojímáme-li subjektivitu jako to, co ve vztahu k prožívanému korelátu ,je tím, čím není“, a „není tím, čím je“, je intencionální život vposled nesmyslný. Skutečný intencionální vztah vyžaduje nejen, aby subjekt uchopoval předměty jako své ne-já, ale také aby subjekt i objekt byly „spleteny“ dohromady či, Husserlovými slovy, obsaženy ,jeden v druhém“ (Ineinander). ${ }^{76}$ Merleau-Ponty tedy předpokládá, že

74 Tamt., str. 61.

75 Rukopis z roku 1958 dochovaný pod titulem La nature ou le monde du silence má sto dvacet osm rukopisných stran, které obsahují třicet šest stran souvislého textu očíslovaných autorovou rukou. Úryvek vydaný Emmanuelem de Saint-Aubertem odpovídá stranám 25-28 autorem číslované části: M. Merleau-Ponty, La nature ou le monde du silence, in: E. de Saint-Aubert (vyd.), Maurice Merleau-Ponty, Paris 2008.

76 M. Merleau-Ponty, Řeč, dějinnost, př́roda, str. 82 a 96; týž, Koncept $k$ Viditelnému a neviditelnému, in: týž, Smysl filosofického tázání, přel. J. Halák, Praha 2009, str. 23-33. 
má-li být možná významuplnost v prožívání, je nezbytné myslet bytí a nebytí, resp. objekt a subjekt, v původní jednotě jako specificky pojaté primordiální bytí. ${ }^{77}$ Toto jednotně chápané bytí je obojím, ovšem jakožto nerozlišený celek neboli prŕroda.

Fenomenologie podle Merleau-Pontyho objevuje bytí přírody prostřednictvím kritiky subjektivně založené ontologie. Zjišt'uje tak, že původním určením bytí není svoboda, jak soudí Sartrův existencialismus, nýbrž spontaneita, nevědomý sebe-klad, který znamená vstup př́rody do výrazu. Až na základě tohoto pojetí bytí a jednoty chce Merleau-Ponty myslet, avšak nikoli z něho dedukovat pojem subjektu. Kritiku „,filosofie svobody“ Merleau-Ponty uzavírá výčtem charakteristik tohoto bytí, které stojí v protikladu k pouhému bytí jakožto objektu, výčtem, který ukazuje míru, v níž si osvojil romantické, zejména pak Schellingovo pojetí přírody, jak je sám vyložil. Příroda je pro něj:

„bytí ... jež nás předchází, obklopuje a nese, které v propletení spolu s námi nese ostatní lidi a je př́stupné z více než jedné perspektivy, jež je zde již před nimi, předchází jim, zakládá je, tvoří vnitřní skloubení každé z nich i skloubení jedné s druhou, [bytí], které ,drží samo od sebe a jež je tím, díky čemu všechny věci drží spolu pohromadě, a které je neredukovatelné na to, čím má každý z nás být.“78

Merleau-Ponty přejímá vymezení přírody jako ontologického základu, principu universální jednoty a nevyčerpatelné spontaneity. Toto vymezení je pro něj východiskem k úvaze o jisté protikladnosti bytí prŕrody, která charakterizuje její vztah k individuovanému jsoucnu. Třebaže je příroda $\mathrm{v}$ jistém ohledu prvním principem, není proto ještě principem absolutním. Příroda není absolutním principem, protože je spontaneitou „podmíněnou“. Její sebevyjadřování nemá charakter tvorby konečného bytí a jsoucna a na svůj výraz je naopak sama odkázána. Z toho důvodu ji není možné pojmout jako východisko filosofické dedukce. Ontologie přírody podle Merleau-Pontyho neposkytuje principy odvozování, nýbrž „učí nás způsoby spojení", mezi něž je na první místo třeba klást ontologický vztah vzájemného vyjadřování, jinde označovaný jako Ineinander neboli splétání. ${ }^{79}$ Proto podle Merleau-Pontyho není filosofie přírody

77 M. Merleau-Ponty, La nature ou le monde du silence, str. 46.

78 Tamt., str. 51.

79 Tamt., str. 52. Husserlův pojem Ineinander Merleau-Ponty překládá jako „splétání“. 
první filosofií v pravém slova smyslu, nýbrž je vůči každé jiné filosofické perspektivě první i druhou. ${ }^{80}$

Jakožto protipól filosofie přírody Merleau-Ponty určuje filosofii dějin nebo také filosofii ducha či filosofii člověka. Z rukopisu vysvítá, že jejím hlavním účelem má být kritika filosofických pojmů uchopujících vztahy, jež se zakládají v prvotně nerozlišeném bytí. ${ }^{81}$ Potřeba této kritiky plyne mimo jiné z Merleau-Pontyho tvrzení, že příroda sama je jaksi výrazem konečné spontaneity. Důsledkem teze o universální vzájemné odkázanosti je, že ačkoli příroda sama není dějinným aktérem, prostřednictvím vyjadřování našeho bytí vstupuje do dějin, a proto i její myšlení musí být dějinné. Důraz na vzájemnou odkázanost všech momentů bytí představuje rys, který, jak ještě uvidíme, zřetelně odlišuje Merleau-Pontyho pojetí od koncepce Patočkovy.

Z Merleau-Pontyho výkladů je zřejmé, jak pojímá jednotlivá jsoucna z hlediska jejich vzájemných vztahů. Vztah mezi zkušeností a vnímanými věcmi na jedné straně a ontologický vztah mezi jsoucny na straně druhé chápe obecně jako poměr vzájemné dynamické implikace. V prvním případě zkušenost vnímajícího rozvíjí smyslové kvality věcí, a naopak vnímané věci rozvíjejí možnosti vnímajícího, takže smyslová kvalita je „Zvláštní modalita naší koexistence se světem“ ${ }^{82} \mathrm{~V}$ druhém př́ípadě zahrnuje analýza vnímání rozbor těchto vztahů na rovině ontologie, takže organismus je co do svého bytí formován svým okolím, které naopak sám v principu týmž způsobem určuje. Z hlediska celku pak Merleau-Ponty chápe jsoucno jako zkonečnění nekonečné spontaneity přírody a jako vyjadřování konečného života $v$ nekonečném. $V$ tomto rámci hovoří Merleau-Ponty o jednotlivém jsoucnu jako takovém v zásadě dvojím způsobem. Z hlediska filosofie dějin je chápe jako výtěžek duchovního úsilí tradice, jejíž distinkce je třeba stále znovu kriticky posuzovat; z hlediska filosofie př́rody je co do své jednotlivosti pojímá jako dále neanalyzovaný fenomenologický fakt. Rozrůzněnost vnímatelného světa je pro něj tudíž vždy určitou zděděnou dějinnou interpretací, která má být korigována pomocí fenomenologie a postavena na základ původní souvislosti jsoucího. Rozlišenost jsoucího, včetně lidského bytí, je tedy

80 Tamt., str. $51 \mathrm{n}$.

81 M. Merleau-Ponty, Proměna vnímání a zkušenost pravdy. Podklady ke kandidatuře na Collège de France, přel. J. Halák, Praha 2017, str. 54. Srv. také M. Merleau-Ponty, Filosof a jeho stín, přel. J. Fulka, in: K. Novotný (vyd.), Co je fenomén?, Praha 2010, str. 85-110, zde str. 92.

82 M. Merleau-Ponty, Proměna vnímání a zkušenost pravdy, str. 54 n. 
pro Merleau-Pontyho něco bytostně relativního, co neobsahuje žádný svébytný prvek, ani si svébytnost nenárokuje.

\section{7.}

Pokusili jsme se ukázat, že Patočkovy strahovské systematické rukopisy a Merleau-Pontyho tvorba věnovaná tématu přírody sdílí obecnou ontologickou tezi. Ta zní,že příroda je nerozlišenost vnitřku a vnějšku, subjektu a objektu, která se nevyčerpatelným způsobem zkonečňuje $\mathrm{v}$ jednotlivém a nese jeho vztahy. Tato obecná teze do značné míry tvoří metafyzickou osnovu obou filosofických stanovisek, avšak oba autoři kladou důraz na odlišný aspekt tohoto základního motivu, takže jejich konkrétní teze nakonec vedou k podstatně rozdílným důsledkům. Na podkladě rámcové shody se nyní pokusíme poukázat na dva body, v nichž se Patočkovo a Merleau-Pontyho pojetí přírody vzájemně zřetelně různí. Originální stránkou Patočkova fenomenologického uchopení rámcové romantické koncepce přírody je jeho důsledné pochopení bytí jako jednotného a zároveň v sobě protikladného - tento aspekt Patočkovy filosofie poukazuje na možnou nedostatečnost Merleau-Pontyho koncepce jednotlivého jsoucna. Specifickým rysem Merleau-Pontyho stanoviska je jeho pojetí př́rody jako vzájemně zcela provázané struktury - tato radikalita Merleau-Pontyho pojmu př́rody kontrastuje s jistou uzavřeností obsaženou v Patočkově pojmu nitra, a tedy i v jeho pojetí lidského života.

Řekli jsme, že výklady Merleau-Pontyho jsou obráceny k pochopení nerozlišenosti a souvislosti jsoucího, zatímco jeho rozrůzněnost v nich co do svého principu není zrretelně vysvětlena. Možný problém zde nepředstavuje otázka distinkcí uvnitř jsoucího, ty tvoří primární obsah Merleau-Pontyho analýz. Jde o to, zda Merleau-Ponty chápe individuaci jako problém v té mîre, v níž za něj pokládá otázku původní provázanosti jsoucího. Jedná se nám, přesněji řečeno, o to, zda individuaci bytí, jež obnáší nárok se ze vztahů v určité mîre vydělit, pokládá za stejně původní jako vzájemnou vztaženost všeho jsoucího. Tento rozměr ontologického myšlení implikuje provedení jisté hodnotové úvahy. Merleau-Ponty přijímá rozlišenost jsoucího jako výchozí danost, již je třeba analyzovat a interpretovat, a to pro něj znamená: objevit její původní souvislost $-\mathrm{v}$ tomto bodě se $\mathrm{s}$ Patočkou shoduje. Na rozdíl od Patočky již ale nepředpokládá, že na základě tohoto kroku je třeba se k jednotlivému vrátit a - na rovině osobního bytí - je učinit tím, čím má být. Stručně řečeno, Merleau-Ponty nechápe individuaci jako cíl. V souladu 
$\mathrm{s}$ tím nepostuluje $\mathrm{v}$ rámci př́rody princip, který by představoval prvotní rozpor a nedostatek $v$ jejím bytí $; 3$ prríroda je $\mathrm{v}$ jeho vyjádřeních sice podmíněna svým zkonečněním, ale mimo to je její bytí prosté veškeré nouze. $Z$ téhož důvodu také Merleau-Pontyho výklad pojmu přírody neobsahuje pojednání o člověku jako o specifickém způsobu bytí, před nějž skutečnost vlastního bytí v rámci přírody staví určitý imperativ či cíl. Z hlediska filosofie strahovských rukopisů se tak Merleau-Pontyho pojetí př́rody jeví jako „objektivní filosofie“, jež klade na první místo poznání celku a člověka chápe jako jednu z jeho částí, protože, Patočkovými slovy, přes „odhodlání proniknout sebe sama ... přeskakuje ... přímo k něčemu, do čeho člověk jest začleněn“ " 84

Patočka naopak chápe př́rodu jako dvojznačnou a v sobě protikladnou. Tendence $\mathrm{k}$ individuálnímu bytí, resp. $\mathrm{k}$ vědomí, je v jeho výkladu pojata jako důvod, proč př́roda vyvěrá ze sebe v podobě nevyčerpatelné spontaneity. Princip různosti či individuality jsoucího tedy podle strahovských rukopisů - a v pravém protikladu k tezi Merleau-Pontyho - tkví přímo v bytí prírody, přesněji řečeno, původní protikladnost přírody není pro Patočku ničím jiným než druhou stranou její jednoty. Individuálnímu charakteru bytí tedy Patočka na rozdíl od Merleau-Pontyho přiznává stejnou původnost jako jeho nerozlišenosti. ${ }^{85}$ Cílem této ontologie proto ve vlastním smyslu není poznání celku ani naplnění individuálního života, ale nalezení vztahu mezi obojím. Princip individuace z tohoto hlediska určuje, jakého stupně vědomí nabývá jednotný život přírody, tedy vymezuje, čím je každé s celkem sjednocené jednotlivé bytí jako takové.

Specifickým určením člověka je podle této filosofie duch. Zakořenění lidského bytí v celku jsoucího a jeho individuace mají na jedné straně podobu horizontové intencionality a na straně druhé intencionality předmětné - tuto distinkci, jež je společným majetkem Husserlových přímých pokračovatelů, Patočka originálně zakládá v protikladu přírody a ducha. Přirozený, spontánní průběh lidského intencionálního života chápe jako mimovolnou objektivaci možností naznačených v horizontovém vědomí - tento život je člověku vlastní, nakolik je neindividuální bytostí, jíž je v různých obdobích svého života v různé míře. ${ }^{86}$ Podstata

83 Přestože Merleau-Ponty sám uvádí, že Schelling takový protiklad zná. Srv. M. Merleau-Ponty, La Nature, str. 61.

84 J. Patočka, Fenomenologické spisy, I, str. 11.

85 Týž, Fenomenologické spisy, III/1, str. 69.

86 Tamt., str. $115 \mathrm{n}$. 
lidského bytí, duch, však podle něj nemůže být realizována uskutečňováním spontánních možností. Spontaneita totiž působí v jednotlivém bytí v rozporu s jeho bytostnou individualitou. Proto má být člověkem zosobněna a zduchovněna. - Jak se z tohoto hlediska jeví stanovisko Merleau-Pontyho? Jeho pojetí přírody zasazuje člověka do vztahů, které nejsou charakteristicky lidské, čímž jej převádí na něco jiného. Protože tato koncepce nezahrnuje specificky lidský moment sebepoznání, není z Patočkova hlediska schopná vyložit ani vzájemné vztahy jsoucího a jednotu celku.

Pojem ducha, který Patočka načrtává v předválečné přednášce $D u c h$ a dvě základní vrstvy intencionality, předpokládá, že člověk se má vědomým způsobem, prostřednictvím reflexe vztáhnout k poslednímu horizontu neboli k celku bytí jako k základní možnosti svého života. Tento čin znamená jisté osvojení všech dílčích horizontů, a v důsledku toho vede k podstatné proměně předmětného zaměření člověka. Takto vypracované rámcové pojetí Patočka rozvíjí a konkretizuje v závěru souvislé části rukopisu Studie k pojmu světa. Zde je rozbor intencionality z předválečné přednášky posazen na právě vypracovaný základ, jímž je koncepce nepředmětného nitra. $\mathrm{V}$ rámci strahovské pozůstalosti tu Patočkovo pojetí naplnění lidského života spatřujeme v jeho nejpropracovanější podobě. Patočka zde vychází od fenomenologického faktu nenaplnitelnosti aktového intencionálního vztahu: každé vyplnění předmětné intence, jakého jsme schopni, ústí nakonec v zpředmětnění míněného a, důsledně vzato, vede náš život pouze k další intenci. ${ }^{87}$ Důvodem je, že lidský život, jakož i život sám má nepředmětný charakter. Odpověd’ na bytostnou negaci objektivace tkví v původní negativitě nepředmětného bytí. Naplnění intencionálního života předpokládá odmítnutí prostého zpředmětnění a prožití jsoucího v jeho původním charakteru, tedy jakožto nepředmětného bytí, jímž je vposled jednotné bytí jako takové. Ponechání jsoucího být v jeho původním charakteru označuje Patočka jako prožití ,dálky“. ${ }^{88}$ Prožití dálky je podle něj passio, které si člověk nevolí, nýbrž ono samo jej zachvacuje. Racionální pochopení tohoto prožitku spontánního života má vyústit v imperativ, v souladu s nímž se člověk činí svobodným vůči bezprostřednosti, a to tím, že v předmětném uznává jeho nezpředmětnitelnost, tedy týž život, z něhož sám žije. Toto naplnění intencionálního života chápe Patočka jako podmínku každého konkrétního životního „programu“.89

87 Tamt., str. $112 \mathrm{n}$.

88 Tamt., str. 118-123.

89 Tamt., str. $120 \mathrm{n}$. 
Ačkoli v závěrečných oddílech Studie neužívá pojmu ducha, jednotlivé kroky jeho úvahy odpovídají starší argumentaci z přednášky Duch a dvě základní vrstvy intencionality: zahlédnutí dálky není ničím jiným než jistým pochopením celku bytí jako nepředmětného, které ústí v proměnu celkového životního horizontu, totiž v jeho osobní převzetí. Vědomý vztah k dálce nadto znamená sjednocení prúrodního a duchovního rozměru lidského bytí. V tomto ohledu Patočkova strahovská koncepce překonává dualitu původního celku a odděleného individua, nebot' moment niternosti a moment předmětnosti v ní mají stejně původní význam. Mám za to, že tento moment, v němž Patočka organicky spojuje mimo jiné romantické pojetí př́ŕrody, Hegelův pojem ducha a Heideggerův koncept starosti, představuje originální prvek filosofie strahovských rukopisů.

Nakonec chci poukázat na možný problematický rys Patočkova imperativu dálky, který má svou obdobu v jeho pojetí přírody. Naplnění lidského intencionálního života Patočka spatřuje ve vztahu lidského nitra k niternosti v jejím celku. Přinejmenším v jednom ohledu však toto naplnění a s ním spojený imperativ dálky pojímá jako vnitřní proměnu, která není nutně spojena se svým projevem navenek. Naplněním imperativu dálky není nic většího ani menšího než akt odmítnutí bezprostředního zpředmětnění. Jedná se tedy o určitý negativní výkon, který patrně neimplikuje žádný nutný pozitivní korelát, jímž by byla určitá objektivace; neobsahuje tedy nárok, aby zosobněné nitro vystoupilo samo ze sebe ven, ani neklade požadavek specifického jednání vůči druhému nitru. Podle Patočkových slov se nutně projevuje pouze v uznání veškeré niternosti jako takové..$^{90}$ Avšak toto uznání má z povahy věci negativní obsah, a jako takové neobnáší žádné projevy navenek ani není jasné, jakým způsobem z něho mají být odvozena vodítka jednání.

Tato absence specifičtěji formulované etiky je zčásti nutným korelátem Patočkovy myšlenky, že nitro nadané duchem má svoji ,podstatu“ v jistém smyslu určit, nebot' nitro samo má nepředmětný charakter. Avšak srovnáme-li toto pojetí s filosofií Merleau-Pontyho, je patrné, že určitá obrácenost či uzavřenost nitra do sebe představuje obecnější rys Patočkova pojmu niternosti. Patočka na rozdíl od Merleau-Pontyho nepředpokládá, že lidské jednání se obráží v bytí přírody, resp. že i příroda sama je odkázána na konečné bytí. Vstupování konečného bytí do výrazu je sice přírodou neseno, v jejím bytí se však nijak neprojevuje. Příroda jako taková je v tomto ohledu vyňata ze sféry lidského jednání, a do

90 Tamt., str. 123. 
sféry odpovědnosti tak spadá pouze co do své rozmanitosti. Universální dějiny veškerého života, o nichž Patočka hovoří v epilogu Přirozeného světa, tak bud’to pojímá pouze jako dějiny prrírody zkonečnělé, anebo jako nezávislé na dějinách ducha. Není tak zřejmé, jak si Patočka universalitu těchto dějin představoval - pokud totiž neexistuje vztah vzájemné odkázanosti i na základní ontologické úrovni, nejde v pravém slova smyslu o dějiny veškerého života. Vynětí přírody ze vzájemného vztahu jsoucího naopak její nepředmětné bytí jaksi „objektivuje“ jakožto o sobě neměnnou strukturu..$^{91}$

U Merleau-Pontyho ustupuje nárok svobody před fascinací vzájemnými vztahy. U Patočky je tento nárok naopak na předním místě v podobě požadavku být vědomou součástí jednoty života. Protože však Patočka nepojímá vzájemné vztahy jsoucího tak radikálně jako Merleau-Ponty, neformuluje nakonec důsledně ani myšlenku svobody lidského života jakožto individuálního života př́rody. ${ }^{92}$

\section{ZUSAMMENFASSUNG}

Der vorliegende Beitrag verfolgt zwei Ziele. Zum einen möchte er das philosophische Konzept beleuchten, das in den sog. Systematischen Strahov-Manuskripten von Jan Patočka enthalten ist und zwar in Bezug auf die Begriffe des Bewusstseins und der Natur. Zum anderen soll dieses philosophische Konzept mit Maurice Merleau-Pontys Thesen über die Natur, die in den Jahren 1956-1961 entstanden sind, verglichen und einige Vorteile und Grenzen von beiden Ansätzen herausgearbeitet werden. Unserer Ansicht nach besteht Patočkas philosophische Konzept auf der einen Seite in einer deskriptiven Analyse der menschlichen Erfahrung, die er als eine vor-reflexive, auf das Bewusstsein der Welt hinweisende Selbstbeziehung versteht. Auf der anderen Seite erklärt Patočka auf der Grundlage dieser deskriptiven Analyse konsequent alles

91 Tuto nejasnost potvrzuje rukopisný úvod k větší filosoficko-dějinné práci nalezený ve strahovské pozůstalosti, jenž byl publikován jako J. Patočka, Filosofie dějin, in: týž, Péče o duši, I, str. 339-352. Patočka v něm pravděpodobně pracuje s koncepcí nitra a jeho duchovního naplnění, jež pojímá jako princip dějin (tamt., str. 350), avšak pojem prrírody či jí odpovídajícího principu v jeho argumentaci nehraje žádnou roli.

92 Tato studie je výsledkem badatelské činnosti podporované Grantovou agenturou České republiky v rámci grantu GA ČR 16-17984Y „Kořeny Merleau-Pontyho převrácení objektivistického paradigmatu v přednáškách z Collège de France“ řě̌eného na Univerzitě Palackého v Olomouci. 
nicht-menschliche Leben, die anorganische Materie und schließlich die gesamte Natur als Leben an sich, dessen Wesen auch in einer gewissen Selbstbeziehung mit einer Tendenz zum Bewusstsein liegt. Der Beitrag stellt weiter kurz Merleau-Pontys Thesen zur Natur vor und vergleicht sie schließlich mit Patočkas Gesamtthesen zur Natur. Der Vorteil von Patočkas Naturbegriff gegenüber dem von Merleau-Ponty besteht darin, dass die Natur bei Patočka sowohl das Prinzip der Einheit als auch der Individualität umfasst. Andererseits liegt der Vorteil von Merleau-Pontys Naturverständnis gegenüber dem von Patočka in der konsequenten Verflechtung des unendlichen Lebens der Natur und des endlichen Lebens der einzelnen Wesen.

SUMMARY

The present article has two objectives. One is to elucidate the philosophical approach presented in the so-called Strahov Systematic Manuscripts of Jan Patočka in terms of consciousness and nature. The other is to compare this philosophical approach with Maurice Merleau-Ponty's theses on nature, as elaborated in 1956-1961, and to point out some advantages and limitations of both approaches. In our opinion, Patočka's philosophical approach consists, on the one hand, in a descriptive analysis of human experience, which he understands as a pre-reflective self-relationship pointing towards the consciousness of the world. On the other hand, on the basis of this descriptive analysis Patočka consequently explicates all non-human life, inorganic matter, and finally the whole of nature as life in its own right, the essence of which is also a certain self-relation with a tendency towards consciousness. The article then briefly presents Merleau-Ponty's theses on nature, and finally compares them with Patočka's overall theses on nature. The advantage of Patočka's notion of nature as against Merleau-Ponty's is that, in Patočka's view, nature encompasses both the principle of unity and individuality. On the other hand, the advantage of Merleau-Ponty's understanding of nature as against Patočka's lies in the consistent interconnectedness of the infinite life of nature and the finite life of individual beings. 